\title{
ANAESTHESIA IN OPHTHALMOLOGY
}

\author{
David A. Rosen, M.D., F.R.C.s. (C) *
}

WITH FEW EXCEPTIONS ophthalmic surgical procedures may be carried out with. either local or general anaesthesia. Operations on children, Imajor orbital procedures, extensive plastic repairs, and very prolonged operations clearly demand general anaesthesia. Apart from these exceptions the ophthalmic surgeon is faced with the choice between local and general anaesthesia. Inevitably personal bias enters into his choice.

\section{Local ANAEsthesla in Ophthalmology}

1. Topical anaesthesia may be achieved with drugs such as cocaine, tetracaine, and dorsacaine. This suffices for such minor procedures as removal of superficially embedded foreign bodies and irrigation of the eye following chemical injury.

2. Infiltration and block anaesthesia are usually achieved with procaine or lidocaine. These may be used with or without added epinephrine and hyaluronidase. For adequate anaesthesia in ophthalmic surgery it is necessary to immobilize the orbicularis and extraocular muscles, as well as to achieve anaesthesia of the ocular structures. Orbicularis block is obtained through either local infiltration of the orbicularis muscle or infiltration of the branches of the facial nerve directed towards this muscle. Paralysis of the extraocular muscles and anaesthesia are obtained by a single retrobulbar injection into the muscle cone.

Local anaesthesia is not without its hazards. Among these are:

(a) Incomplete block of the muscles may permit compression of the globe with expulsion of intraocular contents while the eye is open.

(b) Retrobulbar haemorrhage due to trauma to orbital veins may make the orbit tense and compress the globe, leading to troublesome iris prolapse, precipitous expulsion of the lens, and loss of vitreous.

(c) The injecting needle may penetrate the optic nerve meninges and traumatize the optic nerve.

(d) In instances of posterior staphyloma in high myopia an intraocular injection of the anaesthetic may occur.

(e) The most appreciable hazard, however, relates to the psychological trauma attending the uncomfortable injections themselves, the patient's wakefulness during surgery on an eye, the heat and sense of confinement of the conscious patient beneath the drapes, and his overhearing of the talk that inevitably takes place between the personnel in the operating room, particularly in the course of teaching.

Because of these factors the author has developed a distinct preference for

*Professor of Ophthalmology, Queen's University, Kingston, Ontario.

Can. Anaes. Soc. J.; vol. 9, no. 6, November, 1962 
general anaesthesia in ophthalmic surgery, except for: $(d)$ very minor procedures such as removal of lid cysts, minor lid tumours, and pterygia; $(b)$ the occasional patient who dreads general anaesthesia; $(c)$ the "poor-risk" patient in whom the hazards of general anaesthesia are considered to outweigh the disadvantages of surgery under local anaesthesia.

This preference has been retained despite the fact that local anaesthesia permits more rapid mobilization of the patient and is associated with fewer risks of cardiopulmonary and urinary complications and with a lower incidence of postoperative nausea and vomiting.

\section{General Anaesthesia}

Anaesthetists are familiar with a number of hazards to the eye in anaesthesia for all forms of surgery.

(a) It is frequently stated that patients with glaucoma should not be given atropine for their premedication for fear of precipitating acute glaucoma or of aggravating existing chronic glaucoma. The dangers attending this are, in the author's view, mythical. The amount of atropine that would reach the eye in the doses of atropine ordinarily employed would be infinitesimally small compared with the amount delivered by topical administration of this drug. One drop of 1 per cent atropine contains $0.6 \mathrm{mg}$. of this drug and a sizable fraction of this is probably absorbed into the eye. Considering that the weight of the average eye is $15 \mathrm{gm}$., the amount of atropine that would be present in the entire eye were this drug uniformly distributed in a 70-kilogram individuall given $0.05 \mathrm{mg}$. of atropine in premedication would be only $0.0001 \mathrm{mg}$. Patients who have an anatomical predisposition to angle-closure glaucoma may develop an acute attack as a result of the stress surrounding the surgical procedure in general. Atropine should not be considered an important culprit in this regard.

(b) The possibility of abrasion of the cornea by the anaesthetic mask or drapes must be kept in mind. The lid should be sealed by a bland ophthalmic ointment.

(c) Chemical injuries of the eye by the volatile anaesthetic agents, such as ether, vinethene, and chloroform, can occur and can be enduring. Should any liquid anaesthetic be considered to have entered the conjunctival sac, it should be irrigated liberally with a large volume of saline.

(d) Compression of the eye by an anaesthetic mask, especially in individuals who are hypotensive as a result of anaesthesia, blood loss, or ganglionic-blocking drugs, can result in compression of the central retinal artery and ischaemic changes in the retina and optic nerve. ${ }^{1}$ If this is of sufficient duration retinal infarction can result. The usual systolic pressure in the central retinal artery is $80 \mathrm{~mm} . \mathrm{Hg}$, and digital compression of the eye of surprisingly little force can be observed, with the ophthalmoscope, to obliterate this vessel. Compression should therefore be avoided during surgery.

(e) Occasional idiosyncrasies to anaesthetic dgents resulting in toxic optic neuropathy can occur. Extraocular muscle palsies have occurred following spinal anaesthesia. ${ }^{2}$ 


\section{General AnaesthesLa for Ophthalmic Surgery}

The goals which are sought in ophthalmic surgery include the procurement of an immobile eye in an immobile patient. It is desirable to avoid factors which may result in coughing or vomiting during or after the operation, especially where the resultant ocular compression and raised venous pressure will predispose to wound disruption and haemorrhage. Where these are anticipated pharmacological agents should be employed to inhibit these effects.

Succinylcholine is frequently used to achieve relaxation of the patient during intubation. During the stage of depolarization an increase in tension of the extraocular muscles occurs with compression of the eye. In 50 per cent of instances this results in an increase in intraocular pressure for the duration of action of the drug. ${ }^{3}$ Succinylcholine should therefore not be used after the start of an intraocular procedure. The sudden compression of the globe can lead to disastrous expulsion of intraocular contents. The extraocular muscles appear to be especially sensitive to cholinergic drugs.

A great deal has been written about the oculocardiac reflex in strabismus surgery. ${ }^{4,5}$ It has been found that traction, especially upon the medial rectus muscle, will result in electrocardiographic changes such as nodal thythm, bradycardia, and temporary or permanent cardiac arrest. Electrocardiographic changes have been detected in 30 per cent of the patients in one study. ${ }^{6}$ In frder to reduce the incidence of undesirable oculocardiac reflexes it has been suggested. that patients undergoing strabismus surgery should be intubated and should be kept well ventilated. It has further been suggested that retrobulbar anaesthesia with an agent such as procaine may block the oculocardiac reflex. ${ }^{7}$ This effect of procaine has not been confirmed. ${ }^{8}$ Should the patient exhibit worrisome cardiac slowing the intraveneous injection of atropine will overcome this effect. In the opinion of the author the cardiac complications in strabismus surgery can be prevented by the simple precautions mentioned.

\section{SUMmary}

A cursory review has been made of the place of local and general anaesthesia in ophthalmic surgery. Mention has been made of a number of ocular complications of anaesthesia in general. The author prefers general anaesthesia for all but the most trivial ophthalmic surgical operations.

\section{RÉSUMÉ}

A quelques exceptions prés, la chirurgie ophthalmique se fait à l'aide de l'anesthésie locale ou générale. L'anesthésie générale a des indications nettes: chez les enfants; au cours d'interventions majeures, ou de chirurgie plastique étendue, ou de très longues interventions.

Dans la chirurgie ophthalmique, une anesthésie demande une immobilisation complète des muscles oculaires et extra-oculaires, c'est-à-dire une anesthésie 
complète des structures de l'oeil. Parmi les dangers de l'anesthésie locale, on peut rencontrer:

(a) Un relâchement incomplet des muscles qui peut causer une compression du globe oculaire et une expulsion de son contenu, alors que ce dernier est ouvert.

(b) Une hémorragie rétro-bulbaire due à un traumatisme an niveau des veines orbitaires, hémorragie qui peut exercer une tension sur l'orbite et comprimer le globe oculaire.

(c) Un traumatisme du nerf optique causé par l'aiguille servant à l'injection.

(d) Une injection intra-oculaire de la substance anesthésique dans les staphylomes postérieurs rencontrés dans les cas de myopie grave, par exemple.

(e) Et enfin, parmi les plus grands dangers, le traumatisme psychique dû aux injections oculaires incommodantes, et le fait d'être éveillé durant l'intervention sur l'oeil.

A cause de ces facteurs, l'auteur en est arrivé à avoir une nette préférence pour l'anesthésie générale dans la chirurgie oculaire, sauf, dans les cas mineurs, chez les malades qui redoutent l'anesthésie générale, ou chez les malades qui présentent un mauvais risque, pour lesquels l'anesthésie générale devient un désavantage net en regard de l'anesthésie locale.

Les anesthésistes sont habitués aux risques oculaires, dangers inhérents à l'anesthésie au cours de toutes sortes de chirurgie. Ceux-ci englobent la possibilité d'une ulcération de la cornée, les brulûres chimiques dues aux agẹts anesthésiques volatils, et la compression des yeux par le masque, en particulier chez les gens hypotendus. Parfois une idiosyncrasie aux agents anesthésiques peut provoquer une neuropathie optique toxique. Après une rachi-anesthésie, on peut rencontrer une paralysie des muscles extra-oculaires.

Ce que l'on recherche en chirurgie oculaire, c'est une immobilité complète et des yeux et du malade. Il faut éviter les facteurs qui peuvent faire tousser ou vomir le malade durant, et après l'intervention, en particulier, lorsqu'on sait qu'une compression oculaire et une élévation de la pression veineuse peuvent amener une rupture de la plaie oculaire, et une hémorragie.

La succinylcholine augmente la tension oculaire durant le stade de dépolarisation. Donc, on doit éviter son utilisation dès que la chirurgie intra-oculaire est commencée.

Les réflexes oculo-cardiaques que l'on rencontre, par exemple, dans la chirurgie du strabisme, peuvent être évités par l'intubation et la ventilation adéquate du malade. On a suggéré l'anesthésie rétrobulbaire avec un agent, telle la procaïne, agent qui bloquerait le réflexe oculo-cardiaque. L'atropine, par voie intraveineuse, peut arrêter cette bradycardie embarrassante si elle survient.

Fréquemment, on dit que les malades porteurs d"un glaucome, ne peuvent recevoir de l'atropine en prémédication, car il y aurait danger de crise aigüe de glaucome ou d'aggravation d'un glaucome chronique. Selon l'auteur, ces dangers seraient un mythe, car la quantité d'atropine qui atteindrait l'oeil à partir des doses employées normalement, serait infinitésimale. Les malades prédisposés anatomiquement à faire du glaucome à angle fermé, peuvent développer une crise aigüe due surtout au stress entourant le processus chirurgical en général. 
L'atropine ne devrait pas être considéré comme un agent responsable d'ägraver le glaucome.

\section{REFERENCES}

1. Givner, I., \& JAFFE, N. Occlusion of the Central Retinal Artery Following Anaesthesia. Arch. Ophth. 43: 197 (1950).

2. Biggam, M. J. Paralysis of Ocular Muscles Following Spinal Anaesthesia. Brit. J. Ophth. 16: 552 (1932).

3. KonNBlueth, W.; JaMpolsKy, A.; TAMLER, E.; \& MARG, E. Contractiop of Oculorotary Muscles and Intraocular Pressure. Am. J. Ophth. 49: 1381 (1960).

4. Hoezstra, R. A., \& Planten, J. Oculocardiale Reflexen. Nederl. tijdschr. v. geneesk. 103: 438 (1959).

5. Planten, J. Oculocardiale Reflexen bij Strabismus Operaties. Nederl. tijdschr. v. geneesk. 102: 803 (1958).

6. KIRSCH, R. E. The Prevention of Cardiac Arrest in Ocular Surgery. Survey Ophth. 4: 613 (1959).

7. RrwchuN, M. H. Choice of Anaesthesia in Ophthalmic Surgery. Survey Ophth. 4: 612 (1959).

8. Trope, R. A., \& Rosenzweig, D. Electrocardiographic Changes in Surgery of the Eye. Med. Proc. 6: 40 (1960). 